University of Nebraska - Lincoln

DigitalCommons@University of Nebraska - Lincoln

1999

\title{
Influence of Aqueous and Solid-Phase Fe(II) Complexants on Microbial Reduction of Crystalline Iron(III) Oxides
}

\author{
Matilde Urrutia \\ The University of Alabama, murrutia@biology.as.ua.edu \\ Eric E. Roden \\ The University of Alabama \\ John M. Zachara \\ Pacific Northwest National Laboratory, john.zachara@pnl.gov
}

Follow this and additional works at: https://digitalcommons.unl.edu/usdoepub

Part of the Bioresource and Agricultural Engineering Commons

Urrutia, Matilde; Roden, Eric E.; and Zachara, John M., "Influence of Aqueous and Solid-Phase Fe(II) Complexants on Microbial Reduction of Crystalline Iron(III) Oxides" (1999). US Department of Energy Publications. 216.

https://digitalcommons.unl.edu/usdoepub/216

This Article is brought to you for free and open access by the U.S. Department of Energy at DigitalCommons@University of Nebraska - Lincoln. It has been accepted for inclusion in US Department of Energy Publications by an authorized administrator of DigitalCommons@University of Nebraska - Lincoln. 
Influence of Aqueous and Solid-Phase Fe(II) Complexants on Microbial Reduction of Crystalline Iron(III) Oxides ${ }^{\dagger}$

MATILDE M. URRUTIA, *,

ERICE. RODEN, $\neq A N D$

JOHN M. ZACHARA

Department of Biological Sciences, The University of Alabama, Box 870206, Tuscaloosa, Alabama 35487-0206, and Pacific Northwest National Laboratory, P.O. Box 999, Environmental Dynamics \& Simulation Department, W. R. Wiley Environmental Molecular Sciences Lab, Mail Stop K8-96, Richland, Washington 99352

The influence of aqueous (NTA and EDTA) and solidphase (aluminum oxide, layer silicates) Fe(II) complexants on the long-term microbial reduction of synthetic goethite by Shewanella alga strain BrY was studied. NTA enhanced goethite reduction by promoting aqueous $\mathrm{Fe}(\mathrm{II})$ accumulation, in direct proportion to its concentration in culture medium (0.01-5 mM ). In contrast, EDTA failed to stimulate goethite reduction at concentrations $\leq 1 \mathrm{mM}$, and $5 \mathrm{mM}$ EDTA enhanced the final extent of reduction by only $25 \%$ in relation to nonchelator controls. The minor effect of EDTA compared to NTA, despite the greater stability of the Fe(II)EDTA complex, likely resulted from sorption of $\mathrm{Fe}(\mathrm{II})-$ EDTA complexes to goethite. Equilibrium Fe(II) speciation calculations showed that Fe(II) aq should increase with NTA at the expense of the solid-phase Fe(II) species, whereas the opposite trend was true for EDTA due to Fe(II)EDTA adsorption. The presence of aluminum oxide and layer silicates led to a variable but significant (1.5 to > 3-fold) increase in the extent of goethite reduction. Speciation of Fe(II) verified the binding of $\mathrm{Fe}$ (II) by these solid-phase materials. Our results support the hypothesis that iron(III) oxide reduction may be enhanced by aqueous or solid-phase compounds which prevent or delay Fe(II) sorption to oxide and FeRB cell surfaces.

\section{Introduction}

Microbial iron(III) oxide reduction strongly influences the geochemistry of anaerobic soil and sedimentary environments as well as thepersistenceand mobility of varioustypes of organic and inorganic contaminants in such environments $(1,2)$. Recent studies indicate that the surface chemical properties of both the iron(III) oxide and the dissimilatory $\mathrm{Fe}(\mathrm{III})$-reducing bacteria (FeRB) control the initial rate and long-term extent of microbial reduction of syntheticiron(III) oxides in defined growth medium $(3,4)$. Fe(II) coatings on the surface of iron(III) oxides and FeRB lead to deactivation of Fe(III) reduction as oxide and cell surface sites become

* Correspondingauthor phone: (205)348-5191; fax: (205)348-1403; e-mail: murrutia@biology.as.ua.edu.

† This work is dedicated to the memory of Laureano Urrutia.

₹ The University of Alabama.

$\S$ Pacific Northwest National Laboratory. saturated with sorbed Fe(II). However, reduction can proceed to greater levels than the measured Fe(II) sorption capacity if conditions favor bacterial growth (3). The importance of surface saturation as a passivation mechanism is supported by the observations that Fe(III) reduction can be reactivated if sorbed $\mathrm{Fe}(\mathrm{II})$ is removed from the oxide surface (4) or if fresh FeRB cells are added to Fe(II)-saturated materials (3). Our findings suggest that the extent of iron(III) oxide reduction in anaerobic environments may be influenced by reactions with associated solid phases and aqueous ligands that compete for and complex Fe(II) produced during oxide reduction.

Synthetic chelators such as EDTA and NTA have been shown to play an important role in metal/radionuclide speciation, solubility, and mobility in surface waters and groundwater (5-11). EDTA and NTA complex both Fe(III) and $\mathrm{Fe}(\mathrm{II})$ and may therefore influence the microbial reduction of iron(III) oxides by both dissolution (12) and Fe(II) sequestration (our untested hypothesis). Biogenic Fe(II) may exert a strong impact on the stability of mobile metal/ radionuclide complexes by displacement reactions (13).

Fe(II)-sorbing mineral phases, such as aluminum oxides and layered silicates, may function as alternatesinks for Fe(II), thereby decreasing or delaying iron(III) oxide and bacterial surface saturation with Fe(II). Fe(II) binding by these phases could thus have a direct impact on the activity of FeRB in soil and sedimentary environments as well as the geochemical conditions influenced by their activity, including groundwater $\mathrm{pH}$, alkalinity, and biomineralization. These geochemical effects may strongly influence the mobility of contaminant metals and radionuclides in anaerobic subsurface environments.

In this paper weinvestigate theinfluence of aqueous (NTA, EDTA) and solid-phase (aluminum oxide and layer silicates) complexants on the rateand extent of bacterial iron(III) oxide reduction. Our central hypothesis was that Fe(II) complexation would enhance the long-term reducibility of iron(III) oxides by delaying the formation of passivating oxide/cell surfaceFe(II) coatings. Results indicatethat all of theseFe(II) ligands have the potential to enhance microbial reduction of crystalline iron(III) oxides to some extent, but the biogeochemical interactions are complex and effects are nonlinear.

\section{Material and Methods}

Organism and Culture Conditions. The dissimilatory Fe(III)and $\mathrm{Mn}(\mathrm{IV})$-reducing bacterium Shewanella alga strain $\operatorname{BrY}(14)$ was used as a test organism. S. alga was grown anaerobically in basal culture medium with $\mathrm{H}_{2}$ as electron donor, malate (30 or $8 \mathrm{mM}$ as indicated) as carbon source, and synthetic goethite $\left(50 \mathrm{mmol} \mathrm{L}^{-1} ; 4.45 \mathrm{~g} \mathrm{~L}^{-1}\right)$ as electron acceptor in which the $\mathrm{PO}_{4}{ }^{3-}$ concentration was reduced 100 fold (to $0.04 \mathrm{mM}$ ) relative to the original (15) basal salts composition. The medium was autoclaved prior to the addition of $\mathrm{H}_{2}$ gas. $\mathrm{S}$. alga was grown aerobically to late exponential phasein Tryptic Soy Broth (TSB). The TSB-grown cellswere washed once with $10 \mathrm{mM}$ Pipes buffer (piperazine$\mathrm{N}, \mathrm{N}^{\prime}$-bis\{2-ethanesulfonic acid\}, disodium salt, $\mathrm{pH}$ 6.8), resuspended in buffer to $\sim 10^{8}$ cells $\mathrm{mL}^{-1}$ concentration, and made anaerobic by bubbling with $\mathrm{O}_{2}$-free $\mathrm{N}_{2}$ gas before being used as inoculum $(0.5 \mathrm{~mL}$ of cell suspension to $10 \mathrm{~mL}$ culture tubes). Culture tubes were incubated on their side, without shaking and in the dark at $31{ }^{\circ} \mathrm{C}$. Standard anaerobic techniques were used for all procedures as described in ref 16. 
Synthesis of Fe(III) Goethite. Goethite (Gt) was synthesized and treated as explained previously (3). The mineral obtained had a surface area of $55 \mathrm{~m}^{2} \mathrm{~g}^{-1}$ as determined by five-point BET $\mathrm{N}_{2}$ adsorption.

Influence of EDTA and NTA Concentration on Gt Reduction. Chelators were added to culture tubes $(30 \mathrm{mM}$ malate, $0.04 \mathrm{mM} \mathrm{P,} \mathrm{pH} \mathrm{6.8)} \mathrm{in} \mathrm{triplicate} \mathrm{from} \mathrm{filter} \mathrm{sterilized,}$ anaerobic stock solutions $(1,5,10,50,100$, and $500 \mathrm{mM})$ to obtain final concentrations of $0.01,0.05,0.1,0.5,1.0$, or 5.0 $\mathrm{mM}$. The stocks were prepared with the tetrasodium salt of EDTA ( $\mathrm{Na}_{4} \mathrm{EDTA}$ ) (Fisher Scientific) and the disodium salt of NTA ( $\mathrm{Na}_{2} \mathrm{HNTA}$ ) (Sigma Chem. Co.). Tubes were inoculated with washed TSB-grown S. alga cells immediately following chelator addition. Duplicate sterile controls were included for each chelator concentration. Soluble Fe(II) and Fe(III), and $\mathrm{HCl}$-extractable $\mathrm{Fe}(\mathrm{II})$, were determined at 1, 3, 7, 15, and 30 day intervals.

Effect of Chelators on Fe(II) Adsorption onto Gt. The influence of the chelators on Fe(II) sorption by Gt was evaluated by addition of soluble $\mathrm{Fe}^{2+}$ (added as $\mathrm{FeCl}_{2}$ ) to 50 $\mathrm{mmol} \mathrm{\textrm {L } ^ { - 1 }}$ suspensions of the mineral in the presence and absence of $0.5 \mathrm{mM}$ EDTA or NTA under strictly anaerobic conditions. The Fe(II) sorption capacity of this mineral (in $10 \mathrm{mM}$ Pipes buffer at $\mathrm{pH} 6.9$ without chelators) had been characterized previously (3) as $0.25 \mathrm{mmol} \mathrm{Fe}(\mathrm{II}) \mathrm{g}^{-1}$. EDTA or NTA $(0.1 \mathrm{~mL})$ was added to triplicate $10-\mathrm{mL}$ portions of sterile Gt suspension in Pipes buffer ( $10 \mathrm{mM}$, pH 6.9) from filter sterilized anaerobic stocks. Immediately afterward, a 0.2- $\mathrm{mL}$ aliquot of an anaerobic, filter-sterilized $\mathrm{FeCl}_{2}$ stock solution was added to each tube to obtain Fe(II) concentrations ranging from 0.032 to $5.12 \mathrm{mM}$. Samples were allowed to equilibratefor $18 \mathrm{~h}$ with gentle shaking ( $50 \mathrm{rpm}$ on a rotary shaker), after which the concentration of aqueous Fe(II) [Fe(II $\left.)_{a q}\right]$ was determined as described below. The difference between total added $\mathrm{Fe}(\mathrm{II})$ and $\mathrm{Fe}(\mathrm{II})_{\mathrm{aq}}$ was taken to represent sorbed Fe(II).

Adsorption of $\mathbf{F e}(\mathrm{II})$-Chelator Complexes onto Gt. Equimolar volumes of anaerobic $\mathrm{Fe}(\mathrm{II})\left(\mathrm{as} \mathrm{FeCl}_{2}\right)$ and EDTA (as $\mathrm{Na}_{4} \mathrm{EDTA}$ ) or NTA (as $\mathrm{Na}_{2} \mathrm{HNTA}$ ) solutions (all prepared in $10 \mathrm{mM}$ Pipes buffer at $\mathrm{pH}$ 6.9) were first mixed together in a 1:1 ratio, yiel ding final $\mathrm{Fe}(\mathrm{II})$ and chelator concentrations of $10 \mathrm{mM}$. After a period of $6 \mathrm{~h}$, different amounts of this Fe(II)-EDTA or Fe(II)-NTA solution were added to $50 \mathrm{mmol}$ $\mathrm{L}^{-1}$ suspensions of $\mathrm{Gt}$ (in $10 \mathrm{mM}$ pipes buffer, $\mathrm{pH} 6.9$ ), yielding final Fe(II)-chelator concentrations of $0.01,0.05,0.13,0.33$, 0.5 , and $1 \mathrm{mM}$. After an 18 -h equilibration period with shaking at $50 \mathrm{rpm}, \mathrm{Fe}(\mathrm{II})_{\mathrm{aq}}$ and $0.5 \mathrm{M} \mathrm{HCl}$-extractable $\mathrm{Fe}(\mathrm{II})$ were analyzed. Adsorbed Fe(II) (as Fe(II)-EDTA or Fe(II)-NTA) was calculated from the difference between $\mathrm{Fe}(\mathrm{II})_{\mathrm{aq}}$ and total $\mathrm{Fe}(\mathrm{II})$ extracted in $\mathrm{HCl}$ (see below).

Fe(II) Speciation Calculations. The program MINTEQA2 (17) was used to model the adsorption of Fe(II) onto Gt in the presence of chelators (using the equilibrium constants for Fe(II)-chelator complexes formation included in Table 1, Supporting Information), and the adsorption of Fe(II)chelatorsonto Gt. MINTEQA2 was also used to model results obtained at the end of the reduction experiments in the presence of NTA or EDTA. The modeling approach adopted here is explained in detail elsewhere (3).

Experiments with Solid-PhaseFe(II) Complexants. Two types of experiments were conducted (in $8 \mathrm{mM}$ malate, 0.04 mM P media): some in which goethite, cells and the solidphase Fe(II) sink (either aluminum oxideor layered silicates) were allowed to be in direct contact, and some in which the Fe(II) sink was separated from the goethite and cells by inclusion in a dialysis bag. The later approach allowed the exchange of solutes but avoided contact of the cells with the clay/Al mineral.

The minerals used were $\mathrm{Al}_{2} \mathrm{O}_{3}$ (adsorption gradealumina, 80-200 mesh particle size, Fisher Sci., surface area $113 \mathrm{~m}^{2}$ $\mathrm{g}^{-1}$ ) and three phyllosilicate minerals, commercial kaolin ( $\left.\mathrm{Ka}\right)$ (external surfacearea $16 \mathrm{~m}^{2} \mathrm{~g}^{-1}$ ), Aldrich KSF montmorillonite (KSF) (external surface area $7 \mathrm{~m}^{2} \mathrm{~g}^{-1}$ ), and Aldrich K10 montmorillonite (K10) (external surface area $246 \mathrm{~m}^{2} \mathrm{~g}^{-1}$ ) (all from Aldrich Chem. Co.). Surface areas were obtained by five-point BET $\mathrm{N}_{2}$ adsorption in a Micromeritics Gemini 2360 surface area analyzer, after $2 \mathrm{~h}$ degassing under $\mathrm{N}_{2}$ atmosphere at $200{ }^{\circ} \mathrm{C}$ in a Micromeritics Flowprep 060. $\mathrm{HCl}$ extractable Fe in the layer silicates was determined with 12 $\mathrm{M} \mathrm{HCl}$, yielding values of $0.183 \mathrm{mmol}$ Fe per gram of KSF, $0.064 \mathrm{mmol} \mathrm{g}^{-1}$ for $\mathrm{K} 10$, and only traces $\left(0.0011 \mathrm{mmol} \mathrm{g}^{-1}\right)$ for Ka. Fe(II) and Fe(III) solubilized from themontmorillonites before and after autoclaving (as may occur in culture experiments) were also determined (Table 2, Supporting Information). The KSF montmorillonite produced significant amounts of $\mathrm{HCl}$-extractable $\mathrm{Fe}(\mathrm{II})$ and $\mathrm{Fe}(\mathrm{III})$ upon resuspension in aqueous media as well as some aqueous Fe(II) and $\mathrm{Fe}(\mathrm{III})$. The K10 montmorillonite, on the other hand, contained practically no Fe(II), but some soluble and $\mathrm{HCl}$ extractableFe(III) (Table2, Supporting Information). Because of the Fe content of the montmorillonite clays, total Fe in these reduction experiments was calculated as the sum of $\mathrm{Fe}(\mathrm{III})$ in Gt plusFe(III/II) in the claymineral (when present).

Direct Contact Experiments. Themineral solids wereadded to $50 \mathrm{mmol} \mathrm{L}^{-1} \mathrm{Gt}$ suspensions $\left(248 \mathrm{~m}^{2} \mathrm{~L}^{-1}\right)$ in the following concentrations: 1.0 or $5.0 \mathrm{~g} \mathrm{~L}^{-1}$ of $\mathrm{Al}_{2} \mathrm{O}_{3}$ (total surface area concentration of 113 or $565 \mathrm{~m}^{2} \mathrm{~L}^{-1}$, respectively), 2.6 or 13.0 $\mathrm{g} \mathrm{L}^{-1}$ of $\mathrm{Ka}$ (42 or $208 \mathrm{~m}^{2} \mathrm{~L}^{-1}$, respectively), 3.7 or $18.5 \mathrm{~g} \mathrm{~L}^{-1}$ of KSF (26 or $130 \mathrm{~m}^{2} \mathrm{~L}^{-1}$, respectively) or K10 (910 or 4551 $\mathrm{m}^{2} \mathrm{~L}^{-1}$, respectively) (equivalent to solid in suspension concentrations of 10 and $50 \mathrm{mmol} \mathrm{L}^{-1}$, respectively). Cultures were set up as explained above. Samples were collected aseptically and anaerobically at $1,2,7,9,15,30$, and 40 days after inoculation for Fe(II) determination as described below. Fe reduction was compared to controls with Gt only.

Dialysis Bag Experiments. Dialysis bags (Spectra/Por 1.1 Biotech sterile membranes, $8000 \mathrm{MWCO}, 5 \mathrm{~mL}$ sample volume) were used to prevent bacterial attachment to the solid-phase complexants. In these experiments, $1 \mathrm{~g} \mathrm{~L}^{-1}$ aluminum oxide wassterilized in $1 \mathrm{~mL}$ of $10 \mathrm{mM}$ Pipes buffer ( $\mathrm{pH}$ 6.8) and aseptically transferred into a sterile dialysis bag. The same procedure was used with both concentrations of layer silicates. The bags were then aseptically introduced into anaerobic goethite in culture medium flasks inside an anaerobic chamber. Once resealed, $\mathrm{H}_{2}$ gas was added, and samples were inoculated with $\mathrm{S}$. al ga cells as explained above. Fe reduction was compared to controls with the alternative $\mathrm{Fe}(\mathrm{II})$ sinks in direct contact with $\mathrm{Gt}$. The aluminum oxide and layer silicates inside the dialysis bags were not sampled for Fe(II) until the last sampling date (30 days). For this analysis, cultures were taken into the anaerobic chamber, and the dialysis bags were collected and digested in $0.5 \mathrm{M}$ $\mathrm{HCl}$ (see Analytical Techniques section). The total amount of Fein the goethite suspensions was al so determined at this time. In another repetition of this experiment, triplicate cultures were set up with $1 \mathrm{~g} \mathrm{~L}^{-1}$ aluminum oxide or $2.6 \mathrm{~g}$ $\mathrm{L}^{-1} \mathrm{Ka}$ inside dialysis bags; empty dialysis membranes were introduced in triplicated Gt control cultures as well. Reduction of the Gt by S. alga was followed over time, and the Fe(II) content of dialysis membranes and the mineral complexants were analyzed at the completion of the experiment (30 days) as indicated above.

Adhesion Test. Adhesion of S. alga cells to goethite and aluminum oxide minerals was studied following the method of Caccavo et al. (18), modified for our experimental system. Pipes (10 mM, pH 6.9) was used as adhesion buffer as in all our reduction experiments. Total cell numbers determination was obtained from cell counts in control tubes to which no mineral was added (Pipes only), because neither goethite nor aluminum oxide were dissolved by the methodological 


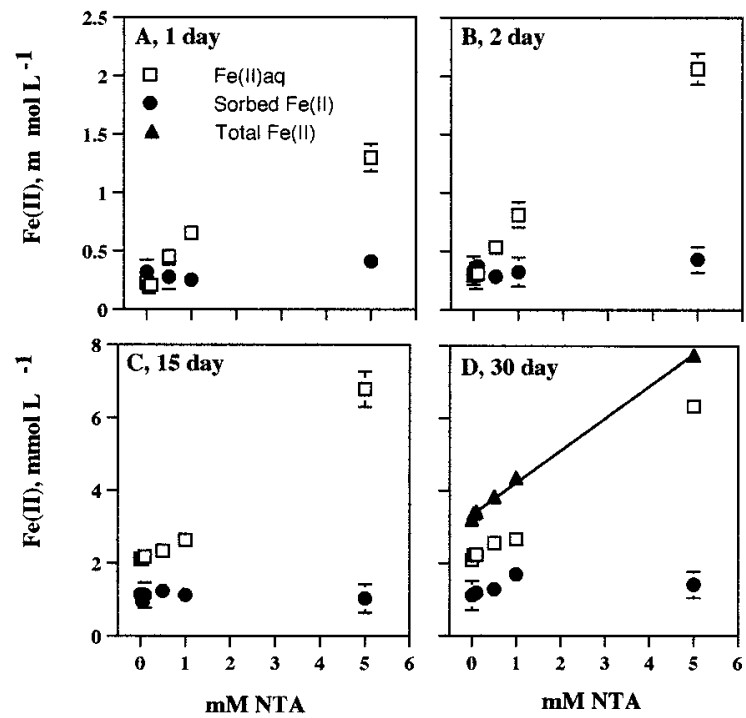

FIGURE 1. Reduction of Gt $\left(50 \mathrm{mmol} \mathrm{L}^{-1}\right)$ by $S$. alga in the presence of different NTA concentrations after 1, 2, 15, and 30 days. Fe(II) w as speciated into soluble $\mathrm{Fe}(\mathrm{II}),(\mathrm{Fe}$ (II) aq), and sorbed Fe(II); total Fe(II) (soluble + sorbed) is included for the $30 \mathrm{~d}$ sample. Data represent the mean \pm standard deviation of triplicate cultures; nonvisible error bars are smaller than the corresponding symbol. The solid line in panel $D$ represents a linear regression analysis of total $\mathrm{Fe}$ (II) as a function of NTA concentration $\left(r^{2}=0.997\right)$.

procedure used in Caccavo et al. (18). Adhesion of cells to aluminum oxide was compared to adhesion to Gt with triplicate tubes in which both minerals were present at equimolar concentrations $(50 \mathrm{mM})$. A triplicate set of tubes with $50 \mathrm{mM}$ Gtand $1 \mathrm{gL}^{-1}$ aluminum oxideas in our reduction experiments was also included.

Analytical Techniques. Total Fe(II) in $0.2-0.5 \mathrm{~mL}$ culture samples was determined by extraction with $5 \mathrm{~mL}$ of $0.5 \mathrm{M}$ $\mathrm{HCl}$ for $2 \mathrm{~h}$, followed by colorimetric analysis of $\mathrm{Fe}(\mathrm{II})$ with ferrozine. Fe(II) aq was measured by filtering a $0.2-1.0 \mathrm{~mL}$ aliquot of sample through a $0.22 \mu \mathrm{m}$ nylon syringe filter directly into ferrozine and reading the $\mathrm{A}_{562}$ immediately. Total Fe in aqueous phase samples and $\mathrm{HCl}$ extracts was obtained by reducing all $\mathrm{Fe}\left(\mathrm{III}\right.$ ) with $\mathrm{NH}_{2} \mathrm{OH} \cdot \mathrm{HCl}$ prior to colorimetric Fedetermination. Fe(III) concentrations werecalculated from the difference between total Fe and Fe(II).

Preliminary experiments showed a very slow color development during the $\mathrm{Fe}(\mathrm{II})$ ferrozine colorimetric assay in the presence of EDTA, most likely dueto competition between EDTA and ferrozine for Fe(II). Therefore, standard curves were prepared with Fe(II) and Fe(III) standard solutions having EDTA concentrations equal to those used in the reduction experiments. Fe(II) $(0.1,0.2,0.5$, and $1 \mathrm{mM})$ was added as ferrous diammonium sulfate, and Fe(III) (0.1, 0.2, 0.5 and $1 \mathrm{mM}$ ) as $\mathrm{FeCl}_{3}$. EDTA concentrations were 0.05, 0.1 , $0.5,1$, and $5 \mathrm{mM}$ for $\mathrm{Fe}(\mathrm{II})$ standard curves and $5 \mathrm{mM}$ for $\mathrm{Fe}(\mathrm{III})$. Both $\mathrm{Fe}(\mathrm{II})$ and $\mathrm{Fe}(\mathrm{III})$ standard curves with $5 \mathrm{mM}$ NTA were also prepared to test the effect of NTA on color development; the presence of NTA did not cause any interference with the assay. Regression equations obtained with each EDTA concentration were used to correct sample $A_{562}$ readings in all subsequent experiments. Neither EDTA nor NTA caused any interference in the determination of $\mathrm{Fe}(\mathrm{III})$.

\section{Results}

Influence of EDTA or NTA on Gt Reduction. The presence of increasing NTA concentrations led to consistent enhancement of the initial $(0-48 \mathrm{~h}) \mathrm{Gt}$ reduction by $\mathrm{S}$. alga, due to increases in Fe(II) aq (Figure 1A,B). A small amount of Fe(III)
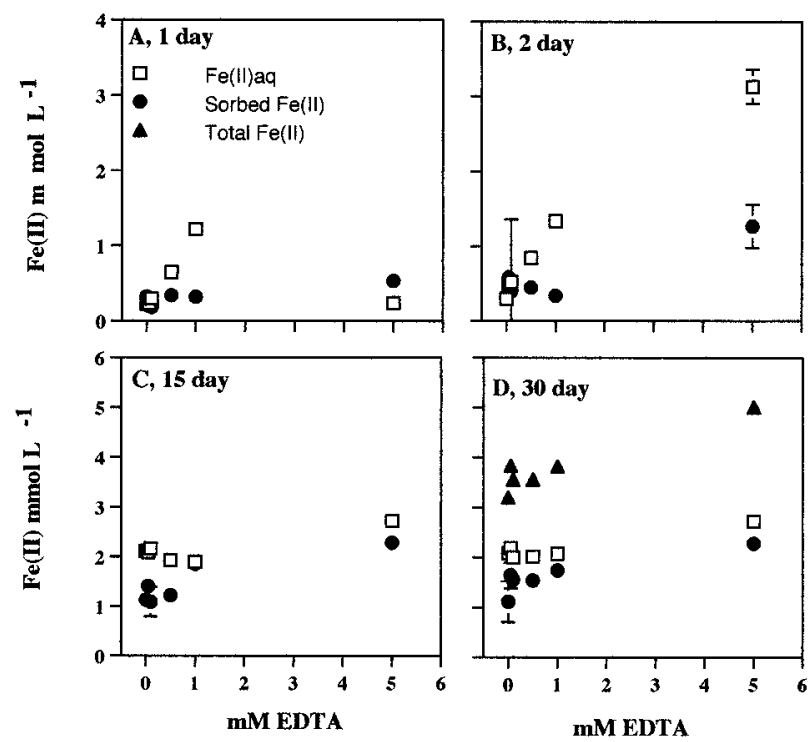

FIGURE 2. Reduction of $\mathrm{Gt}\left(50 \mathrm{mmol} \mathrm{L}^{-1}\right)$ by $S$. alga in the presence of several EDTA concentrations at 1, 2, 15, and 30 days. Fe(II) was speciated into soluble (Fe(II) aq) and sorbed Fe(II); total Fe(II) (soluble + sorbed) is included for the $30 \mathrm{~d}$ sample. Data represent the mean \pm standard deviation of triplicate cultures; nonvisible error bars are smaller than the corresponding symbol.

(maximum of $15 \mu \mathrm{mol} \mathrm{Fe}(\mathrm{III}) \mathrm{L}^{-1}$ ) was dissolved from Gt by the highest NTA concentration (5 $\mathrm{mM})$ in sterile controls (data not shown), whereas no $\mathrm{Fe}(\mathrm{III})_{\text {aq }}$ was ever detectable in NTA-amended S. alga cultures. After a week to 1 month of incubation, Fe(III) reduction increased proportionally ( $r^{2}$ $=0.997$ ) to NTA concentration (Figure 1D). The increase in $\mathrm{Fe}(\mathrm{III})$ reduction was caused by solubilization of $\mathrm{Fe}(\mathrm{II})$ by NTA; there was no substantial effect of NTA on sorbed Fe(II) (closed circles).

The presence of increasing concentrations of EDTA noticeablyenhanced initial Gt reduction by $S$. alga in relation to the nonchelator controls (Figure 2A,B). As with NTA, this effect was due to increases in the $\mathrm{Fe}(\mathrm{II})_{\mathrm{aq}}$ fraction (open squares in figure). The only exception was the samples to which $5 \mathrm{mM}$ EDTA was added (Figure 2A). EDTA solubilized up to $25 \mu \mathrm{mol} \mathrm{Fe}(\mathrm{III}) \mathrm{L}^{-1}$ from goethite after 2 days and up to $100 \mu \mathrm{mol} F e(I I I) L^{-1}$ after 30 days in the sterile controls amended with 0.5 or $1 \mathrm{mM}$ EDTA. Fe(III) aq was negligible in EDTA-amended S. alga cultures. The long-term extent of Gt reduction was not significantly increased by addition of EDTA atconcentrations $\leq 1 \mathrm{mM}(p<0.01)$ (Figure 2D). Thecultures that received $5 \mathrm{mM}$ EDTA over time also showed increases in both $\mathrm{Fe}(\mathrm{II})_{\mathrm{aq}}$ and sorbed $\mathrm{Fe}(\mathrm{II})$ (Figure $2 \mathrm{~B}, \mathrm{C}$ ). The final extent of goethite reduction was enhanced $25 \%$ by $5 \mathrm{mM}$ EDTA in relation to the nonchelator controls (Figure 2D).

Influence of EDTA and NTA on Fe(II) Sorption by Goethite. Fe(II) adsorption isotherms were conducted in the presence of $0.5 \mathrm{mM}$ NTA or EDTA under $\mathrm{pH}$ and ionic strength conditions identical to those in the Gt reduction experiments (Figure $3 \mathrm{~A}, \mathrm{~B}$ ). The presence of $0.5 \mathrm{mM}$ NTA reduced Fe(II) sorption at low $\mathrm{Fe}(\mathrm{II})$ loadings but did not significantly affect the amount of $\mathrm{Fe}(\mathrm{II})$ sorbed at near saturation levels (Figure 3A). The presence of $0.5 \mathrm{mM}$ EDTA had a similar effect(Figure 3B). Fe(II) sorption at low Fe(II) loadings was slightly greater in the presence of EDTA than in the presence of NTA. The point on the isotherm below which the chelators influenced $\mathrm{Fe}(\mathrm{II})$ sorption is $10^{-3.3} \mathrm{~mol} \mathrm{~L}^{-1}$, which is the added chelator concentration. This result was foreseen, sincechelators would be expected to affect Fe(II) sorption only when the total chelator concentration is greater than the total Fe(II) concentration. 

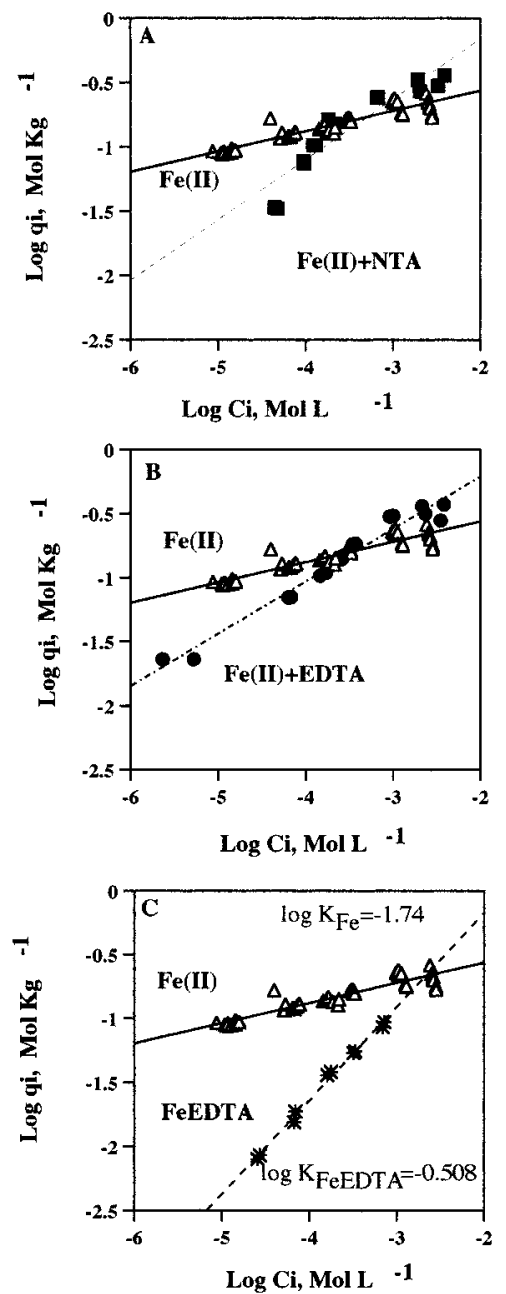

FIGURE 3. $\mathrm{Fe}$ (II) adsorption onto goethite $\left(50 \mathrm{mmol} \mathrm{L}^{-1}\right)$ in the presence of NTA or EDTA. (A) Freundlich plot for Fe(II) adsorption onto Gt in the presence of $0.5 \mathrm{mM}$ NTA (Fe(II) + NTA) (solid squares 口). (B) Freundlich plot for Fe(II) adsorption onto $\mathrm{Gt}$ in the presence of $0.5 \mathrm{mM}$ EDTA (Fe(II) + EDTA) (solid circles 9 ). (C) Freundlich plot for adsorption of Fe(II)-EDTA complexes onto Gt (FeEDTA) (stars *). A previously determined (3) isotherm for uncomplexed Fe(II) adsorption to the same Gt mineral in the absence of chelators is included in each panel as a reference (open triangles $\Delta$ ) (reproduced with permission from the publisher, Taylor \& Francis, Ltd). Each point represents an individual sample. $\mathrm{Ci}=$ soluble $\mathrm{Fe}$ (II) at equilibrium; qi $=$ adsorbed $\mathrm{Fe}(\mathrm{II})$ at equilibrium; Freundlich equations: $\mathrm{Fe}(\mathrm{II})$ adsorption in Pipes buffer, $y=0.158 x-0.246, r^{2}$ $=0.858 ; \mathrm{Fe}$ (II) adsorption in the presence of $0.5 \mathrm{mM} \mathrm{NTA}, y=0.469 \mathrm{x}$ $+0.777, r^{2}=0.860$; Fe(II) adsorption in the presence of $0.5 \mathrm{mM}$ EDTA, $y=0.409 x+0.609, r^{2}=0.965$; FeEDTA adsorption, $y=0.733 x$ $+1.287, r^{2}=0.993$. Log $K_{F}$ values in (C) are derived from activity Freundlich transforms of the data using MINTEQA2.

Adsorption of Fe(II)-Chelator Complexesonto Goethite. Adsorption of Fe(II)-EDTA to Gt was low at low sorbate concentrations but at high loadings approached the levels of uncomplexed Fe(II) adsorption (Figure 3C). Theadsorption data were fit to an activity Freundlich adsorption model using MINTEQA2 $\left(\log K_{F}=-0.508\right)$. Fe(II)-NTA complexes sorbed much less strongly than Fe(II)-EDTA (data not shown).

Calculated Fe(II) Speciation. The equilibrium speciation of Fe(II) was computed as a function of chelator concentration (Table 3 ) to assess the potential solid and aqueous phase associations of biogenic Fe(II). Thetotal Fe(II) concentration chosen for these calculations was $3.2 \mathrm{mmol} \mathrm{L}^{-1}$, equal to the average amount of reduction obtained in the nonchelator controls at the end of the experiment (Figures 1D and 2D).
Values for Fe(II)-chelator complexes equilibrium constants are compiled in Table 1, Supporting Information. Although the experimental Fe(II) speciation obtained in Fe reduction experiments is not always accurately described by these computations ((3)), they should nevertheless give an idea of the major speciation trends in the presence of the chelators. $\mathrm{Fe}(\mathrm{II})$ speciation calculations in the presence of EDTA $(0.5-5$ $\mathrm{mM}$ ) were conducted to obtain equilibrium concentrations for all the Fe(II)-EDTA species. The most abundant Fe(II)EDTA species under these conditions, FeEDTA ${ }^{2-}$, was then considered to be the sorbing species. FeEDTA ${ }^{2-}$ adsorption to Gt was then included with an activity Freundlich model (Figure 3C); for each EDTA concentration, the initial total FeEDTA ${ }^{2-}$ was the equilibrium concentration for this species obtained previously. This approach allowed FeEDTA ${ }^{2-}$ to distribute between FeEDTA ${ }^{2-}$ aq and FeEDTA ${ }^{2-}$ sorbed according to the measured isotherm (Figure $3 \mathrm{C}$ ). These calculations revealed significant increases in FeEDTA ${ }^{2-}$ sorbed with increasingEDTA concentration that took place at the expense of the aqueous components (Table 3 ). These results agreed with the $\mathrm{Fe}(\mathrm{II})$ speciation observed in Gt reduction experiments in the presence of EDTA (Figure 2), in which there was an increasein the sorbed Fe(II) fraction in relation to nonchelator controls (note that solid-phase Fe(II) determinations do not differentiate what chemical species of Fe(II) is being measured).

Cal culations for Fe(II) speciation in the presence of NTA $(0.5-5 \mathrm{mM})$ indicated that FeNTA ${ }^{-}$was the predominant $\mathrm{Fe}(\mathrm{II})$-NTA species for NTA concentrations $\leq 1 \mathrm{mM}$, whereas both FeNTA ${ }^{-}$and FeNTA ${ }_{2}{ }^{4-}$ were equally abundant at $5 \mathrm{mM}$ NTA levels (Table 3 ). Increasing concentrations of NTA led to stepwise increases in $\mathrm{Fe}(\mathrm{II}) \mathrm{NTA}_{\mathrm{aq}}$ species at the expense of vivianite $\left(\mathrm{Fe}_{3}\left(\mathrm{PO}_{4}\right)_{2} \cdot 8 \mathrm{H}_{2} \mathrm{O}\right), \mathrm{Fe}(\mathrm{II})$ - mal ate complexes, and $\mathrm{Fe}(\mathrm{II})_{\text {sorbed }}$ (from a total of $0.86 \mathrm{mmol} \mathrm{L}^{-1}$ in absence of NTA to $0.13 \mathrm{mmol}^{-1}$ with $5 \mathrm{mM}$ NTA). Sorption of FeNTA ${ }^{-}$species (FeNTA ${ }^{-}$sorbed) was computed to be very low based on experimental data (Table3). Consolidated budgets for Fe(II) aq and solid-phase Fe(II) for this exercise showed that Fe(II) aq would increase with increasing NTA concentrations through solubilization of the solid-phase Fe(II) fraction (Table 3). These results wereconceptually consistent with experimental observation (Figure 1).

Solid-Phase Fe(II) Sinks. The reduction of goethite by S. alga was suppressed when $\mathrm{Al}_{2} \mathrm{O}_{3}$ particles were in direct contact with Gt and cells (Figure 4A,B, filled diamonds). Cell adhesion assays showed that the cells adhered much strongly to Gt than to al uminum oxide, but there was measurablecell adhesion to the Al mineral. Overall a $70-75 \%$ cells were adhered in tubes with Gt (with or without al uminum oxide) versus around $20 \%$ in tubes with aluminum oxide only. When thealuminum oxidewasenclosed insidea dialysis bag, which allowed exchange/diffusion of solutes but avoided contact between cells and the $\mathrm{Al}_{2} \mathrm{O}_{3}$, Gt was reduced more readily than in the absence of the Al mineral (Figure 4, open circles). At the end of the experiment, the alumina inside the dialysis bag had bound up to $12 \mathrm{mmol} \mathrm{Fe}^{-1}$, which represents $25 \%$ of the $\mathrm{Fe}(\mathrm{III})$ present initially in the goethite. Overall, the total amount of Fe(III) reduced in this system was approximately $35 \%$ of the total, in comparison to $7-10 \%$ reduced in absence of the aluminum oxide. A subsequent experiment (Figure 5) confirmed that Gt reduction was promoted by the presence of aluminum oxide due to sorption/ binding of Fe(II) onto theAl mineral and the dialysis bag(Figure 5), sincesomeFe(II) was also bound by the dialysis bag itself.

Kaolinite in direct contact with the cells/goethite decreased Gt reduction (data not shown). When Ka was placed in a dialysis membrane, approximately $15 \%$ of the initial $\mathrm{Fe}(\mathrm{III})$ content was bound as Fe(II) by $\mathrm{Ka}$ at the end of the 
TABLE 3. Calculated Fe(II) Speciation (MINTEQA2) in Presence of Different Concentrations of NTA or EDTA ${ }^{b}$

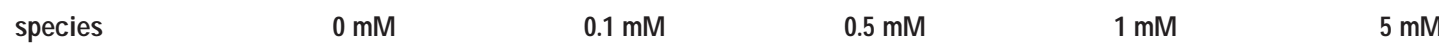

\begin{tabular}{|c|c|}
\hline $\mathrm{Fe}^{2+}$ & $2.1 \times 10^{-4}$ \\
\hline $\mathrm{FeHPO}_{4 a q}$ & $1.3 \times 10^{-7}$ \\
\hline FeMalate & $2.1 \times 10^{-3}$ \\
\hline FeNTA $^{1-}{ }_{a q}$ & 0 \\
\hline $\mathrm{FeNTA}_{2}{ }^{4-}$ & 0 \\
\hline FeHNTA & 0 \\
\hline FeOHNTA $^{2-}$ & 0 \\
\hline $\mathrm{Fe}_{\text {sorbed }}{ }^{a}$ & $8.6 \times 10^{-4}$ \\
\hline Vivianite $^{a}$ & $5.6 \times 10^{-5}$ \\
\hline FeNTA $^{1-a_{\text {sorbed }}}$ & 0 \\
\hline $\mathrm{Fe}(\mathrm{II}) \mathrm{aq}$ total & $2.3 \times 10^{-3}$ \\
\hline Solid-phase total & $9.2 \times 10^{-4}$ \\
\hline $\mathrm{Fe}^{2+}$ & $2.1 \times 10^{-4}$ \\
\hline $\mathrm{FeHPO}_{4 \mathrm{aq}}$ & $1.3 \times 10^{-7}$ \\
\hline FeMalate & $2.1 \times 10^{-3}$ \\
\hline FeEDTA $^{2-}$ aq & 0 \\
\hline FeHEDTA $^{-}$ & 0 \\
\hline FeOHEDTA $^{3-}$ & 0 \\
\hline $\mathrm{Fe}(\mathrm{OH})_{2} \mathrm{EDTA}^{4-}$ & 0 \\
\hline $\mathrm{Fe}_{\text {sorbed }}{ }^{a}$ & $8.6 \times 10^{-4}$ \\
\hline Vivianite $^{a}$ & $5.6 \times 10^{-5}$ \\
\hline FeEDTA $^{-2 a_{\text {sorbed }}}$ & 0 \\
\hline Fe(II)aq total & $2.3 \times 10^{-3}$ \\
\hline Solid-phase total & $9.1 \times 10^{-4}$ \\
\hline
\end{tabular}

$\begin{array}{ll} & \text { NTA } \\ 2.0 \times 10^{-4} & 1.7 \times 10^{-4} \\ 1.3 \times 10^{-7} & 1.4 \times 10^{-7} \\ 2.0 \times 10^{-3} & 1.7 \times 10^{-3} \\ 9.8 \times 10^{-5} & 4.8 \times 10^{-4} \\ 2.4 \times 10^{-7} & 6.8 \times 10^{-6} \\ 1.3 \times 10^{-9} & 6.4 \times 10^{-9} \\ 1.6 \times 10^{-8} & 7.9 \times 10^{-8} \\ 8.4 \times 10^{-4} & 7.7 \times 10^{-4} \\ 5.5 \times 10^{-5} & 5.4 \times 10^{-5} \\ 4.1 \times 10^{-7} & 7.3 \times 10^{-7} \\ 2.3 \times 10^{-3} & 2.4 \times 10^{-3} \\ 9.0 \times 10^{-4} & 8.2 \times 10^{-4}\end{array}$

EDTA

$2.0 \times 10^{-4}$

$1.3 \times 10^{-7}$

$2.0 \times 10^{-3}$

$3.0 \times 10^{-5}$

$7.6 \times 10^{-9}$

$5.8 \times 10^{-7}$

$3.6 \times 10^{-9}$

$8.4 \times 10^{-4}$

$5.6 \times 10^{-5}$

$6.9 \times 10^{-5}$

$2.2 \times 10^{-3}$

$9.6 \times 10^{-4}$
$1.7 \times 10^{-4}$
$1.4 \times 10^{-7}$
$1.7 \times 10^{-3}$
$2.1 \times 10^{-4}$
$3.8 \times 10^{-8}$
$2.9 \times 10^{-6}$
$1.8 \times 10^{-8}$
$7.7 \times 10^{-4}$
$5.4 \times 10^{-5}$
$2.9 \times 10^{-4}$
$2.1 \times 10^{-3}$
$1.1 \times 10^{-3}$

$1.4 \times 10^{-4}$
$1.6 \times 10^{-7}$
$1.4 \times 10^{-3}$
$9.2 \times 10^{-4}$
$3.2 \times 10^{-5}$
$1.2 \times 10^{-8}$
$1.5 \times 10^{-7}$
$6.8 \times 10^{-4}$
$5.2 \times 10^{-5}$
$9.3 \times 10^{-7}$
$2.5 \times 10^{-3}$
$7.3 \times 10^{-4}$

$8.1 \times 10^{-6}$

$7.2 \times 10^{-8}$

$7.8 \times 10^{-5}$

$1.4 \times 10^{-3}$

$1.6 \times 10^{-3}$

$1.9 \times 10^{-8}$

$2.4 \times 10^{-7}$

$1.3 \times 10^{-4}$

0

$1.4 \times 10^{-7}$

$3.1 \times 10^{-3}$

$1.3 \times 10^{-4}$

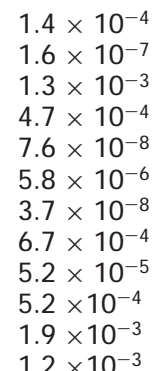

$3.5 \times 10^{-11}$

$3.1 \times 10^{-13}$

$3.4 \times 10^{-10}$

$1.8 \times 10^{-3}$

$2.4 \times 10^{-7}$

$1.9 \times 10^{-5}$

$1.3 \times 10^{-7}$

$1.3 \times 10^{-7}$

0

$1.4 \times 10^{-3}$

$1.8 \times 10^{-3}$

$1.4 \times 10^{-3}$

${ }^{a}$ Solid-phase Fe(II). ${ }^{b}$ The total Fe(II) concentration in the modeled system $\left(3.2 \times 10^{-3} \mathrm{M}\right)$ was equal to the amount generated during reduction experiments in the nonchelator cultures (see text). Only major species are presented. Concentrations are in units of mol L-1.
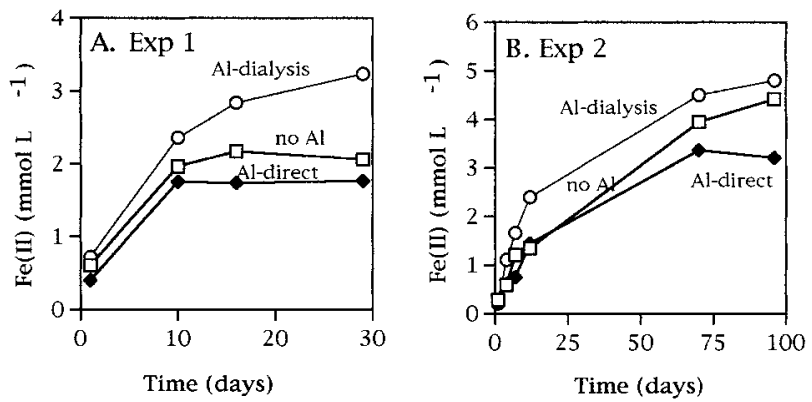

FIGURE 4. Reduction of Gt $\left(50 \mathrm{mmol} \mathrm{L}^{-1}\right)$ by $S$. alga in the presence of $\mathrm{Al}_{2} \mathrm{O}_{3}\left(1 \mathrm{~g} \mathrm{~L}^{-1}\right)$ inside a dialysis bag (open circles) or in direct contact $w$ ith the cells (filled diamonds) in comparison to a non$\mathrm{Al}_{2} \mathrm{O}_{3}$ control (no Al, open squares). (A) Initial experiment. (B) Second experiment. Fe(II) concentrations reflect the Fe(II) content of the Gt suspension only (dialysis bag was not analyzed until the final sampling date). Data represent the mean \pm standard deviation of triplicate cultures; nonvisible error bars are smaller than the corresponding symbol.

experiment (Figures 5 and 6), enhancing Gt reduction by 2-fold.

The presence of $\mathrm{K} 10$ or KSF montmorillonites in direct contact with the cells either had no effect or slightly hindered Gt reduction (data not shown). When the montmorillonites were enclosed inside the dialysis bag, the total amounts of $\mathrm{Fe}(\mathrm{II})$ determined in the Gt suspension (outside the dialysis bag) werelower than in direct contact experiments. However, the K10 and KSF inside the dialysis bag bound significant quantities of $\mathrm{Fe}(\mathrm{II})$ at experiment termination, which led to a dramatic increase in total Fe(II) production (Figure 6).

\section{Discussion}

Effect of Synthetic Chelators. Previous studies suggested that NTA stimulated iron(III) oxide reduction in aquifer sediments due to solubilization of Fe(III), since laboratory tests (with $\sim 2-4 \mathrm{mM} \mathrm{NTA}$ ) demonstrated this chelator's

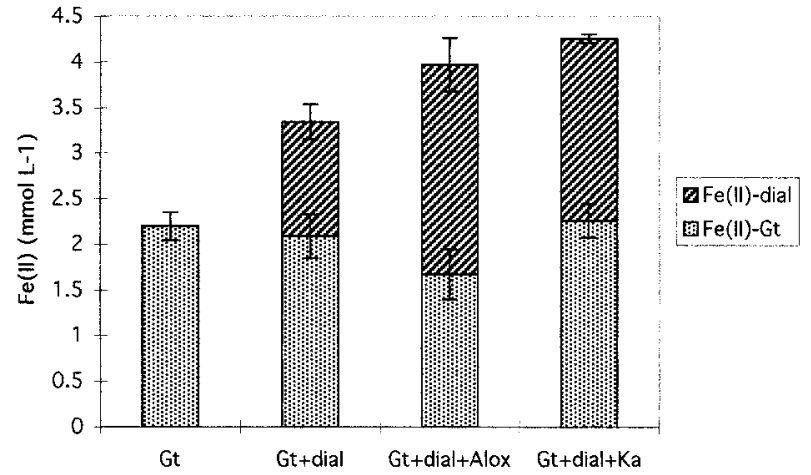

FIGURE 5. Reduction of $\mathrm{Gt}\left(50 \mathrm{mmol} \mathrm{L}^{-1}\right)$ by $S$. alga with or without $\mathrm{Al}_{2} \mathrm{O}_{3}\left(1 \mathrm{~g} \mathrm{~L}^{-1}\right)$ or kaolinite $\left(2.6 \mathrm{~g} \mathrm{~L}^{-1}\right)$ within dialysis bags after 30 d incubation. Control cultures containing an empty dialysis bag were included. Fe-Dial: $\mathrm{HCl}$-extractable $\mathrm{Fe}$ (II) contained in the dialysis bag and the enclosed solid. Fe-Gt: $\mathrm{HCl}$-extractable $\mathrm{Fe}$ (II) from goethite at the end of the experiment. Data represent mean \pm standard deviation of triplicate cultures.

ability to solubilize Fe(III) from amorphous iron oxides (12). Our results suggest that chelators can stimulate crystalline iron(III) oxide (goethite) reduction by this same mechanism, although the magnitude of the effect is much reduced due to the lower solubility of goethite. This solubilization effect was demonstrated by the enhanced initial rates of reduction with increasing chelator concentrations (Figures 1 and 2). The solubilization effect was more significant with EDTA (Figure 2) than NTA (Figure 1), because EDTA is a stronger $\mathrm{Fe}(\mathrm{III})$ ligand $\left(\log \mathrm{K}_{\mathrm{Fe}(I I I) \mathrm{NTA}}=17.83, \log \mathrm{K}_{\mathrm{Fe}(I I I) \text { EDTA }}=27.57\right.$, (19)). EDTA solubilized more Fe(III) in sterile controls, with maximum values of $100 \mu \mathrm{mol} \mathrm{L}^{-1}$ after 1 week for 0.5 and 1 mM EDTA concentrations. Similar levels of goethite dissolution (between 40 and $60 \mu \mathrm{M} \mathrm{Fe}(\mathrm{III})$ ) by $>1 \mathrm{mM}$ EDTA were reported by Davis and Upadhyaya (20).

Our results demonstrate that an even greater impact of chelators on iron(III) oxide reduction results from aqueous $\mathrm{Fe}(\mathrm{II})$ complexation. Formation of soluble Fe(II) complexes 


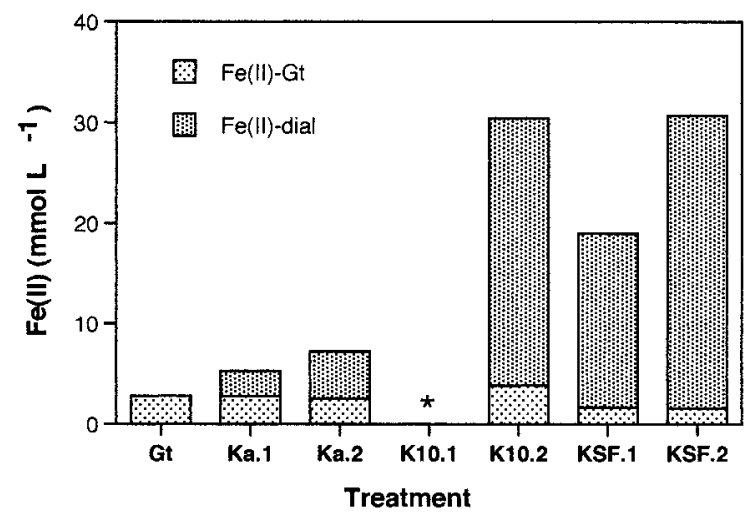

FIGURE 6. Reduction of Gt $\left(50 \mathrm{mmol} \mathrm{L}^{-1}\right)$ by $S$. alga in the presence of layer silicates placed inside dialysis bags after a $30 \mathrm{~d}$ incubation. Data for montmorillonites (K10 and KSF) w as correc ted for (1) soluble $\mathrm{Fe}(\mathrm{III})$ released from the clays to the grow th medium after autoclaving (see Table 2) and (2) $\mathrm{HCl}$-extractable Fe(II) content of clays.* culture lost. Nomenclature: $\mathrm{Ka} .1=2.6 \mathrm{~g}_{\text {clay L }}^{-1} ; \mathrm{Ka} .2=13 \mathrm{~g} \mathrm{clay} \mathrm{L}^{-1} ; \mathrm{K}^{-10.1}$ $=3.7 \mathrm{~g} \mathrm{clay} \mathrm{L}^{-1} ; \mathrm{K} 10.2=18.5 \mathrm{~g} \mathrm{clay} \mathrm{L}^{-1} ; \mathrm{KSF} .1=3.7 \mathrm{~g} \mathrm{clay} \mathrm{L}^{-1} ; \mathrm{KSF}^{2} 2$ $=18.5 \mathrm{~g}_{\text {clay }} \mathrm{L}^{-1}$.

in NTA amended cultures led to increases in Fe(II)aq concentration in direct proportion to the chelator concentration (Figure 1). These increases in Fe(II) aq were associated with a parallel increase in total Fe(III) reduction. In similar manner, complexation of evolved Fe(II) during iron(III) oxide reduction promoted reduction of goethitein the presence of the much weaker (compare log $\mathrm{K}_{\mathrm{Fe}(I) \text { ) malate }}=3.48$ with values in Table 1, Supporting Information) organic chelator malate (3). Speciation calculations indicated that aqueous Fe(II)NTA species formed mainly at the expense of the solid-phase Fe(II) pool (Table 3), particularly at NTA concentrations greater than $1 \mathrm{mM}$, and that sorption of Fe(II)-NTA species to Gt was insignificant. These cal culations suggest that NTA enhanced bacterial reduction of goethite through formation of solubleFe(II) complexes. The decreasein Fe(II) adsorption to Gt (Figure 3A) when NTA was in greater than equimolar concentration further support this conclusion.

In the case of EDTA, we observed that Fe(II)-EDTA complexes adsorbed to goethite (Figure 3C). Several metalEDTA complexes are known to sorb to iron(III) oxides with increasing affinity at lower $\mathrm{pH}(21-23)$, including both $\operatorname{Fe}(I I I)-\operatorname{EDTA}(7,8,24,25)$ and Fe(II)-EDTA (13). Theselater authors observed that Fe(II)EDTA ${ }^{2-}$ complexes, which formed through dissociation of Co(II)EDTA ${ }^{2-}$ in their system, exhibited comparable sorptivity to both the starting and bioreduced goethite mineral.

Sorption of Fe(II)EDTA ${ }^{2-}$ may partly account for the increases in sorbed Fe(II) observed in samples amended with $5 \mathrm{mM}$ EDTA (Figure 2D). Such sorption may also be reponsible for the smaller effect of EDTA, compared to NTA, on Gt reduction despite the higher stability of the Fe(II)EDTA $^{2-}$ complex (log $\mathrm{K}=15.98$ for $\mathrm{Fe}(\mathrm{II}) \mathrm{EDTA}^{2-}$ vs $\log \mathrm{K}=$ 9.85 for Fe(II)NTA ${ }^{-}$, Table 1, Supporting Information). The $\mathrm{Fe}(\mathrm{II})$ speciation calculations that included adsorption of FeEDTA $^{2-}$ to Gt (Table 3), which showed that there was no predicted increase in $\mathrm{Fe}(\mathrm{II})_{\text {aq }}$ with increasing EDTA concentrations, support this conclusion.

Effect of Complexing Solids. Our initial experiments showed that aluminum oxide in direct contact with FeRB inhibited Gt reduction. Tests indicated that cells adhered to aluminum oxide, although to a lesser extent than to Gt ( 20\% adhesion to $\mathrm{Al}_{2} \mathrm{O}_{3}$ vs $70-75 \%$ adhesion to $\mathrm{Gt}$ ). A $20 \%$ reduction of the initial cell concentration added at inoculation $(\sim 5 \times$ $10^{8}$ cells $\mathrm{mL}^{-1}$ ) would leave an active population of approximately $4 \times 10^{8}$ cells $\mathrm{mL}^{-1}$. Previous observations found significant decreases in Fe(III) reduction rates (of both HFO and Gt) with decreasing cell densities, particularly for cell densities lower than $6 \times 10^{8}$ cells $\mathrm{mL}^{-1}$ (4). Hence it is reasonable to expect an apparent decrease in Gt reduction in direct contact experiments due to adhesion of cells onto the accompanying aluminum oxide.

The argument and data above were further corroborated by the enhancement of Gt reduction observed when the aluminum oxidewasenclosed in a dialysis bag that prevented adhesion of the cells to the aluminum oxide (Figures 4 and 5). In this case, approximately equal quantities of Fe(II) were found in the Gt suspension and aluminum oxide at completion of the experiment (Figure 5), overall doubling the total amount of Gt reduced in relation to thenon-aluminum oxide control. Fe(II) sorption capacities for these minerals (normalized to surface area) are $6.4 \mu \mathrm{mol} F\left(\right.$ II) $\mathrm{m}^{-2}$ for the Gt and $4.4 \mu \mathrm{mol} \mathrm{Fe}(\mathrm{II}) \mathrm{m}^{-2}$ for the $\mathrm{Al}_{2} \mathrm{O}_{3}$. After 30 days incubation, around $25 \%$ of the total $\mathrm{HCl}$-extractable $\mathrm{Fe}(\mathrm{II})$ in the growth medium ( $8 \mathrm{mM}$ malate, $0.04 \mathrm{mM} \mathrm{P}$ ) is present as $\mathrm{Fe}(\mathrm{II})_{\text {aq. }}$. Therefore, for the data presented in Figure 5, Gt was approximately $75 \%$ saturated with $\mathrm{Fe}$ (II) $(5.05 \mu \mathrm{mol} \mathrm{Fe}(\mathrm{II})$ $\mathrm{m}^{-2}$ ), and the aluminum oxide had about 1.5 times more $\mathrm{Fe}(\mathrm{II})\left(6.9 \mu \mathrm{mol} \mathrm{Fe}(\mathrm{II}) \mathrm{m}^{-2}\right)$ than the measured saturation level $\left(4.4 \mu \mathrm{mol} \mathrm{Fe}(\mathrm{II}) \mathrm{m}^{-2}\right.$ ). These results suggest that the $\mathrm{Fe}(\mathrm{II})$ sorption by the aluminum oxidemineral and, possibly, surface precipitation mechanisms serve to partition Fe(II) away from active reduction surfaces on Gt and FeRB cells, thereby promoting the extent of Gt reduction.

The presence of the silicates in direct contact with cells and Gt generally did not enhance Fe(II) production (data notshown). Layer silicates and iron(III) oxides (27) or bacterial walls (28) have been shown to form aggregates when in contact. Therefore, blockage of surfacesites involved in Fe(III) reduction via aggregation may have been responsiblefor the observed results. When this physical impediment was removed (dialysis bag experiments), the presence of kaolinite (Ka) (Figures 5 and 6) or montmorillonite (K10 and KSF) (Figure 6) greatly promoted the long-term extent of Gt reduction by $\mathrm{S}$. alga.

Our results demonstrate that, under appropriate conditions, al uminum oxides and layer silicates enhance bacterial iron(III) oxide reduction by drawing biogenic Fe(II) away from the iron(III) oxide and cell surfaces. The solid-phase complexants competefor Fe(II) and delay surface passivation of the iron(III) oxide and cells. The inhibition of reduction which occurred in the direct contact experiments is not meaningful for natural environments, because established in situ populations of FeRBs would preferentially colonize the surfaces of the iron(III) oxides. In soils and sediments, layer silicates and aluminum/iron oxides are commonly found as discrete phases and, as such, could perpetuate the reduction of iron(III) oxides by the mechanisms mentioned above.

In conclusion, the long term extent of iron(III) oxide reduction may be enhanced by aqueous or solid-phase complexants which prevent Fe(II) sorption to the iron oxide and to the bacterial cells. NTA, aluminum oxide, and layer silicate minerals all enhance bacterial iron(III) oxide reduction. In the case of solid-phase Fe(II ) complexants, however, physical effects such as adsorption of thecellsto non-iron(III) oxide surfaces and/or aggregate formation hindered the positive effect on Fe(III) reduction. EDTA enhanced thelongterm extent of reduction only at very high concentrations, probably as a result of Fe(II)EDTA ${ }^{2-}$ complexes sorption to theiron(III) oxidesurface. It isfeasi blethat in an open system in which reaction products are eliminated, EDTA may also enhance the total extent of reduction by a continued solubilization of Fe(III). However, under nonflow conditions, concentrations of EDTA lower than $1 \mathrm{mM}$ will not have a substantial effect on the amount of Fe reduced from crystalline iron(III) oxides by FeRB. In the case of NTA, our 
results suggest that even low levels of chelator in an advective flow field could substantially enhance the degree of oxide reduction by complexing evolved Fe(II). Other Fe(II) ligands (natural humic or organic acids) could play a similar role. Collectively these findings emphasize the need for including the fate of biogenic Fe(II) in mechanistic models of the rate/ extent of iron(III) oxide reduction in sedimentary environments.

\section{Acknowledgments}

We would like to thank Ginger Scott for conducting the laborious cell counts. This research was supported by the Subsurface Science Program, Office of Health and Environmental Research, U.S. Department of Energy (DOE), and by the DOE-EMSP Program through Grant No. DE-FG0796ER62321. Pacific Northwest National Laboratory is operated for DOE by Battelle Memorial Institute under contract DE-AC06-76RLO 1830.

\section{Supporting Information Available}

Tables of equilibrium constants for formation of Fe(II)chelator complexes used in equilibrium speciation calculations, and $\mathrm{HCl}$-extractableand soluble Fe(II) and $\mathrm{Fe}$ (III) from the KSF and K10 montmorillonites before and after autoclaving suspensions in growth medium. This material is availablefree of chargevia the Internet athttp:// pubs.acs.org.

\section{Literature Cited}

(1) Lovley, D. R. Microbiol. Rev. 1991, 55, 259-287.

(2) Lovley, D. R. J Ind Microbiol 1995, 14, 85-93.

(3) Urrutia, M. M.; Roden, E. E.; Fredrickson, J. K.; Zachara, J. M. Geomicrobiol. J. 1998, 15, 269-291.

(4) Roden, E. E.; Zachara, J. M. Environ. Sci. Technol. 1996, 30, $1618-1628$

(5) Girvin, D. C.; Gassman, P. L.; Bolton, J. H. Soil Sci. Soc. Am. J. 1993, 57, 47-57.

(6) Jardine, P. M.; Taylor, D. L. Geoderma 1995, 67, 125-140.

(7) Szecsody, J. E.; Zachara, J. M.; Bruckhart, P. L. Environ. Sci. Technol. 1994, 28, 1706-1716.

(8) Zachara, J. M.; Smith, S. C.; Kuzel, L. S. Geochim. Cosmochim. Acta 1995, 59, 4825-4844.
(9) Xue, H.; Sigg, L.; Kari, F. G. Environ. Sci. Technol. 1995, 29, $59-68$.

(10) Bolton, H., Jr.; Li, S. W.; Workman, D. J.; Girvin, D. C. J. Environ. Qual. 1993, 22, 125-132.

(11) Gonsior, S. J.; Sorci, J. J.; Zoellner, M. J.; Landenberger, B. D. J. Environ. Qual. 1997, 26, 957-966.

(12) Lovley, D. R.; Woodward, J. C. Chem. Geol. 1996, 132, 19-24.

(13) Zachara, J. M.; Smith, S. C.; Fredrickson, J. K. Geochim. Cosmochim. Acta Submitted for publication.

(14) Rosselló-Mora, R. A.; Caccavo, F., Jr.; Osterlehner, K.; Springer, N.; Spring, S.; Schuler, D.; Ludwig, W.; Amann, R.; Vanncanneyt, M.; Schleifer, K. H. System. Appl. Microbiol. 1994, 17, 569-573.

(15) Lovley, D. R.; Phillips, E. J. P. Appl. Environ. Microbiol. 1988, $54,1472-1480$.

(16) Lovley, D. R.; Phillips, E. J. P. Appl. Environ. Microbiol 1987, 53, 1536-1540.

(17) Allison, J.D.; Brown, D. S.; Novo-Gradac, K.J. U.S. Environmental Protection Agency, Athens, GA, 1991.

(18) Caccavo, F. J.; Schamberger, P. C.; Keiding, K.; Nielsen, P. H. Appl. Environ. Microbiol. 1997, 63, 3837-3843.

(19) Smith, R. A.; Martell, A. E. NIST Standard referencedatabase46; U.S. Department Commerce: Gaithersburg, MD, 1997.

(20) Davis, A. P.; U padhyaya, M. Water Res. 1996, 30, 1894-1904.

(21) Zachara, J. M.; Gassman, P. L.; Smith, S. C.; Taylor, D. Geochim. Cosmochim. Acta 1995, 59, 4449-4463.

(22) Bowers, A. R.; Huang, C. P. J. Colloid Interface Sci. 1986, 110, 575-590.

(23) Rueda, E. H.; Grassi, R. L.; Blesa, M. A. J. Colloid Interface Sci. 1985, 106, 243-246.

(24) Nowack, B.; Sigg, L. J. Colloid Interface Sci. 1996, 177, 106-121.

(25) Nowack, B.; Lutzenkirchen, J.; Behra, P.; Sigg, L. Environ. Sci. Technol. 1996, 30, 2397-2405.

(26) Grantham, M. C.; Dove, P. M.; DiChristina, T. J. Geochim. Cosmochim. Acta 1997, 61, 4467-4477.

(27) Swartz, C. H.; Ulery, A. L.; Gschwend, P. M. Geochim. Cosmochim. Acta 1997, 61, 707-718.

(28) Walker, S. G.; Flemming, C. A.; Ferris, F. G.; Beveridge, T. J.; Bailey, G. W. Appl. Environ. Microbiol. 1989, 55, 2976-2984.

Received for review April 21, 1999. Revised manuscript re ceived August 24, 1999. Accepted August 30, 1999.

ES990447B 